\title{
Pengembangan Media Pembelajaran Video Animasi Berbasis ADDIE pada Pembelajaran Tema 5 Cuaca untuk Siswa Kelas III Sekolah Dasar
}

\author{
Elza Izzaturahma ${ }^{1 *}$, Luh Putu Putrini Mahadewi², Alexander Hamonangan \\ Simamora ${ }^{3}$ \\ 1,2,3 Program Studi Teknologi Pendidikan, Universitas Pendidikan Ganesha, Singaraja, Indonesia
}

\section{ART I C L E I N F O}

Article history:

Received August 18, 2021

Revised August 20, 2021

Accepted September 30, 2021

Available online December 25, 2021

Kata Kunci:

ADDIE, Media Video Animasi,

Tematik

Keywords:

ADDIE, animated Video Media Thematic

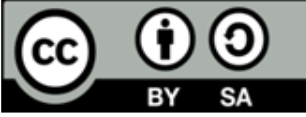

This is an open access article under the CC BY-SA license.

Copyright (C) 2021 by Author. Published by Universitas Pendidikan Ganesha.

\begin{abstract}
A B S T R A K
Rumusan masalah dan tujuan penelitian yaitu mendeskripsikan rancang bangun media video animasi pada pelajaran tema 5 cuaca untuk siswa kelas III semester ganjil di sekolah dasar dan mendeskripsikan validitas media video animasi pada pelajaran tema 5 cuaca untuk siswa kelas III semester ganjil di sekolah dasar. Jenis penelitian ini yaiatu kualitatif dan kuantitatif. Model penelitian ini menggunakan model ADDIE. Subjek penelitian ini yaitu satu ahli desain pembelajaran, satu ahli media pembelajaran, satu ahli isi pembelajaran, tiga orang siswa uji coba perorangan, dan sembilan orang siswa uji coba kelompok kecil. Metode pengumpulan data menggunakan metode pencatatan dokumentasi, metode wawancara, metode observasi, dan metode kuesioner. Instrumen penelitian menggunakan lembar pencatatan dokumen, lembar kuesioner, dan lembar wawancara. Analisis data yang digunakan adalah analisis deskriptif kualitatif dan deskriptif kuantitatif. Hasil penelitian pada tujuan penelitian yang pertama yaitu rancang bangun media video animasi dengan menggunakan tahap pengembangan ADDIE. Pada tujuan penelitian yang kedua dengan melihat hasil validitas menyimpulkan bahwa pada hasil oleh uji ahli desain pembelajaran dengan skor $88 \%$ dengan kualifikasi baik, uji ahli media pembelajaran dengan skor $95 \%$ dengan kualifikasi sangat baik, uji ahli isi pembelajaran dengan skor $94 \%$ dengan kualifikasi sangat baik, uji coba perorangan dengan skor $93,34 \%$ dengan kualifikasi sangat baik, dan uji coba kelompok kecil dengan skor $92,94 \%$ deangan kualifikasi sangat baik.
\end{abstract}

\section{A B S T R A C T}

The research formulates the problem and research objectives, namely to describe the design of animated video media in the 5-weather theme lesson for odd semester third-grade students at Elementary School, and describe the validity of animated video media in the 5-weather theme lesson for odd semester third-grade students in elementary school. Primary school. This type of research is qualitative and quantitative. This research model uses the ADDIE model. The subjects of this research are one learning design expert, one instructional media expert, one learning content expert, three individual trial students, and nine small group trial students. Methods of data collection using the method of recording documentation, interview methods, observation methods, and questionnaire methods. The research instrument used a document recording sheet, questionnaire, and interview sheet. Analysis of the data used is a descriptive qualitative analysis and quantitative descriptive. The results of the research on the first research objective, namely the design of animated video media using the ADDIE development stage, in the second research objective by looking at the validity results concluded that the results by the learning design expert test with a score of $88 \%$ suitable qualification, the learning media expert test with a score $95 \%$ of very good qualifications, learning content expert test with a score of $94 \%$ very good qualification, individual trials with a score of $93.34 \%$ very good qualifications, and small group trials with a score of $92.94 \%$ very good qualifications. 


\section{PENDAHULUAN}

Perkembangan teknologi, informasi, dan komunikasi semakin pesat dan sangat membantu masyarakat, terutama di pendidikan. Kehadiran teknologi, informasi, dan komunikasi membantu para masyarakat di berbagai aspek seperti aspek kehidupan seperti politik, budaya, sosial, ekonomi, dan pendidikan. Perkembangan teknologi, informasi, dan komunikasi selalu menuntut dunia pendidikan agar bisa memanfaatkan teknologi, informasi, dan komunikasi. Teknologi digunakan untuk memecahkan dan menyelesaikan masalah yang muncul dalam dunia pendidikan (Angga et al., 2020). Pembelajaran tematik merupakan pendekatan pembelajaran yang dibagi beberpa komptensi dasar dan indikator serta disatukan dengan satu tema (Siddiq et al., 2020). (Siddiq et al., 2020) berpendapat bahwa siswa harus terlibat aktif dan berpotensi memecahkan masalah, sehingga menimbulkan krativitas dan berpatisipasi dalam pemecahan masalah. Terdapat tiga hal yang harus diperhatikan saat pembelajaran tematik yaitu, menyusun penerapan pembelajaran, penerapan pembelajaran, dan evaluasi atau penilain pembelajaran (Antika et al., 2019; Siddiq et al., 2020).

Kenyataanya ialah saat ini masih banyak guru yang menerapkan pembelajaran secara konvensional yang berdampak pada hasil belajar siswa dan berdampak pada kurangnya motivasi pembelajaran siswa. Dalam aspek verbal, guru sering menggunakan pembelajaran dengan metode ceramah, padahal guru selalu dituntut untuk memfasilitasi pembelajaran secara kreatif dan inovatif (Siddiq et al., 2020; Sukarini \& Manuaba, 2021). Hal ini berkaitan dengan hasil wawancara dan observasi yang dilakukan pada semester ganjil tahun akademik 2019/2020 dan pada saat tahun ajaran semester genap tahun 2020/2021 di SD Negeri 1 Banjar Bali. Diketahui bahwa guru cenderung menggunakan metode yang konvensional melalui ceramah dan tanya jawab. Dalam pembelajaran daring ini, guru hanya mengirimkan materi video dari youtube dan mengirimkan power point ke grup whatsapp kelas III. Berdasarkan hasil pencatatan dokumen di SD Negeri 1 Banjar Bali dengan wali kelas III diperoleh informasi bahwa pencapaian hasil belajar siswa belum optimal, terutama pada muatan pelajaran Matematika. Serta peserta didik masih saja pasif dan lebih menggunakan pembelajaran dengan menggunakan buku paket dan media video yang diambil di youtube dan memanfaatkan media pembelajaran dengan power point. Selain itu, berdasarkan hasil pengisian angket yang diberikan kepada siswa kelas III di SD Negeri 1 Banjar Bali bahwa sebanyak 81\% dengan 17 siswa dari 21 siswa lebih senang belajar menggunakan media audio visual daripada media e-handout, e-modul, buku paket, dll. Pada proses pembelajaran melalui daring, peserta didik lebih lambat mengumpulkan tugas atau tepat waktu dikarenakan mereka tidak mempunyai gadget dan hanya orang tua peserta didik yang mempunyai gadget tersebut. rang tua peserta didik mengumpulkan tugas langsung ke sekolah secara tatap muka dan para guru selalu ada di sekolah. Selain itu, selama pembelajaran daring ini peserta didik belum maksimal mengimplementasikan ICT (information communication technologies) dan membuat bahan ajar.

Untuk mendukung terlaksananya pembelajaran jarak jauh dengan optimal, maka diperlukan media pembelajaran. Media pembelajaran yaitu media video animasi. Media video animasi adalah media yang berupa isi gambar-gambar yang dikumpulkan dan dibuat bergerak sesuai dengan kebutuhan (Kasih, 2017; Sukarini \& Manuaba, 2021). Video animasi merupakan sebuah program komputer yang digunakan dalam penyampaian materi dengan kombinasi berupa teks, gambar, warna, animasi, dan audio dengan memiliki kesatuan yang utuh (Antika et al., 2019; Awalia et al., 2019; Sukarini \& Manuaba, 2021). Kelebihan video animasi ini adalah perpaduan unsur-unsur seperti, audio, video, teks, animasi, gerak yang menjadi satu sehingga menjadi media yang sangat menarik (Maulida, Lubis, \& Solin, 2019; Dewi \& Negara 2021; Sumarni et al., 2020). Video animasi dikatakan menarik karena memiliki manfaat video yaitu: 1) menarik perhatian, 2) memperindah tampilan dan membuat unik pembelajaran, 3) mempermudah sistematis pembelajaran, 4) memahami pembelajaran siswa, 5) mampu memperjelas materi yang sulit (Ayuningsih, 2017; Candra Dewi \& Negara, 2021; Kasih, 2017). Temuan penelitian sebelumnya menyatakan bahwa video animasi ini membantu guru dan membantu siswa dalam pembelajaran serta efektif dalam meningkatkan hasil belajar siswa (Candra Dewi \& Negara, 2021; Siddiq et al., 2020; Dewi, N. W. U. R., Asril, N. M., \& Wirabrata, D. G. F., 2021; Wiradinata et al., 2013). Temuan penelitian sebelumnya juga menyatakan bahwa hasil belajar meningkat dan membangkitkan motivasi (Ponza et al., 2018; Sukarini \& Manuaba, 2021; Rachmavita, F. P., 2020). Dapat disimpulkan bahwa media pembelajaran yang bersifat inovatif dan menumbuhkan keingintahuan siswa adalah video animasi yang membantu dan mengembangkan inovasi, meningkatkan keingintahuan, dan memotivasi siswa. Alasan memilih video animasi karena video animasi memiliki beragam kombinasi dan perpaduan dengan konten materi, sehingga siswa bisa memahami materi yang disampaikan. Di samping itu, video animasi dapat mempermudah guru melaksanakan pembelajaran.

\section{METODE}

Jenis penelitian ini adalah penelitian pengembangan (Research and Development/R\&D). Penelitian dan pengembangan (Research and Development/ $R \& D$ ) dalam arti luas adalah penggunaan usaha kreatif dan 
pengetahuan yang dilakukan sistematis berdasarkan dalam aplikasi baru dalam rangka meningkatkan pengetahuan ilmiah dan teknis (Buchdadi et al., 2018). Penelitian ini dilakukan di SD Negeri 1 Banjar Bali, yang terletak di Banjar Bali, Kecamatan Buleleng, Kabupaten Buleleng, Provinsi Bali. Subjek dalam penelitian ini di antaranya 1) ahli isi pembelajaran, 2) ahli desain pembelajaran, 3) ahli media pembelajaran, 4) uji ahli perorangan siswa kelas III di SD, dan 5) uji ahli kelompok kecil siswa kelas III di SD. Ahli isi pembelajaran merupakan seorang guru yang mengajar di SD Negeri 1 Banjar Bali. Ahli desain dan media pembelajaran merupakan seorang dosen yang mengajar di Program Sudi Teknologi Pendidikan, Universitas Pendidikan Ganesha. Subjek uji coba perorangan adalah 3 orang siswa kelas III di SD Negeri 1 Banjar Bali yang terdiri dari siswa berkemampuan tinggi, sedang, dan rendah. Subjek uji coba kelompok kecil adalah 9 orang siswa kelas III di SD Negeri 1 Banjar Bali yang terdiri dari siswa 3 orang siswa berkemampuan tinggi, 3 orang siswa sedang, dan 3 orang siswa rendah. Model penelitian ini menggunakan tahap ADDIE yang memberi peluang untuk melakukan evaluasi terhadap aktivitas pengembangan pada setiap tahap, (Tegeh dan Wawan, 2019). Model ADDIE memiliki lima tahapan yaitu: (1) analisis (analyze), (2) perancangan (design), (3) pengembangan (development), (4) implementasi (implementation), dan (5) evaluasi (evaluation).

Metode yang digunakan dalam penelitian ini adalah (1) metode wawancara, (Agung, 2018). Wawancara ini digunakan untuk mengumpulkan data dan penyampaian informasi dari hasil penelitian. (2) metode kuesioner (angket) digunakan untuk mengumpulkan data tanggapan siswa sesuai dengan analisis karakteristik peserta didik, hasil review ahli bidang isi atau mata pelajaran, ahli media pembelajaran, ahli desain pembelajaran, hasil dari uji coba perorangan, dan uji coba kelompok kecil. (3) metode observasi, (Agung, 2018) merupakan suatu cara untuk mengadakan penilaian yang dilakukan secara langsung atau di tempat penelitian yang secara sistematis. Jadi, dapat disimpulkan bahwa observasi adalah pengamatan dan pencatatan secara sistematik dengan unsur-unsur yang terlihat dari tempat penelitian tersebut. (4) metode pencatatan dokumen digunakan untuk mengumpulkan data berupa hasil belajar siswa, RPP, dan silabus.

Instrumen penelitian ini menggunakan (1) Lembar kuesioner, digunakan untuk mengumpulkan data review dari uji ahli isi mata pelajaran, ahli desain pembelajaran, ahli media pembelajaran, uji coba kelompok kecil, dan uji coba perorangan. (2) Lembar wawancara, digunakan untuk mengajukan pertanyaan-pertanyaan oleh kepada guru. Wawancara dilakukan untuk mengumpulkan informasi dan permasalahan yang terjadi selama proses pembelajaran. (3) Laporan pencatatan dokumen digunakan pada saat mengumpulkan data perkembangan produk mulai dari tahap analisis sampai desain, seperti bahanbahan untuk mengembangkan produk. Adapun kisi-kisi instrumen ahli desain pembelajaran dalam penelitian ini disajikan pada Tabel 1. Kisi-kisi instrumen ahli isi pembelajaran dalam penelitian pengembangan animasi dua dimensi ini dapat disajikan pada Tabel 2. Kisi-kisi instrumen uji coba perorangan uji dan coba kelompok kecil dalam penelitian pengembangan video animasi ini dapat disajikan pada Tabel 3.

Tabel 1. Kisi-kisi Instrumen Ahli Desain Pembelajaran

\begin{tabular}{|c|c|c|c|}
\hline No & Aspek & Indikator & $\begin{array}{c}\text { Jumlah } \\
\text { Butir }\end{array}$ \\
\hline 1 & $\begin{array}{l}\text { Kejelasan } \\
\text { Pesan }\end{array}$ & $\begin{array}{ll}\text { a. } & \text { Penyajian materi memotivasi siswa untuk belajar } \\
\text { b. } & \text { Penyajian materi menarik minat siswa ntuk belajar } \\
\text { c. } & \text { Penjelasan informasi sangat memudahkan dan membantu. }\end{array}$ & 3 \\
\hline 2 & $\begin{array}{l}\text { Menarik } \\
\text { Perhatian }\end{array}$ & $\begin{array}{l}\text { a. Video memaparkan persembahan visual yang menarik } \\
\text { b. Video memaparkan persembahan visual yang menyenangkan bagi } \\
\text { siswa. }\end{array}$ & 2 \\
\hline 3 & $\begin{array}{l}\text { Visualisasi } \\
\text { Media }\end{array}$ & $\begin{array}{ll}\text { a. } & \text { Kejelasan sistematika dan alur materi. } \\
\text { b. Kejelasan gambar, simbol, ikon. } \\
\text { c. } \\
\text { d. Kuran gambar, simbol, ikon sesuai dengan materi. } \\
\text { e. Ketepatan letak objek teks maupun gambar. } \\
\text { f. } & \text { Ketepatan dalam penggunaan bahasa. } \\
\text { g. } & \text { Kejelasan materi yang disampaikan dalam media } \\
\text { h. } & \text { Petunjuk media dalam media mudah dimengerti } \\
\end{array}$ & 8 \\
\hline & & Jumlah & 13 \\
\hline
\end{tabular}


Tabel 2. Kisi-Kisi Instrumen Ahli Isi Pembelajaran

\begin{tabular}{|c|c|c|c|}
\hline No & Aspek & Indikator & Jumlah Butir \\
\hline 1. & Kejelasan Pesan & $\begin{array}{l}\text { a. Penggunaan contoh yang dipaparkan relevan. } \\
\text { b. Kejelasan materi dalam kompetensi dasar. } \\
\text { c. Kejelasan materi dalam indikator pencapaian. } \\
\text { d. Kejelasan materi dalam tujuan pembelajaran. } \\
\text { e. Kejelasan materi mudah dipahami. }\end{array}$ & 5 \\
\hline \multirow[t]{2}{*}{2.} & Representasi Isi & $\begin{array}{l}\text { a. Ketepatan contoh-contoh dalam memahami materi. } \\
\text { b. Ketepatan isi materi. } \\
\text { c. Kebenaran konsep materi. } \\
\text { d. Materi yang dipaparkan relevan. } \\
\text { e. Kejelasan penyajian materi }\end{array}$ & 5 \\
\hline & & Jumlah & 10 \\
\hline
\end{tabular}

Tabel 3. Kisi-Kisi Instrumen Uji Coba Perorangan Uji Dan Coba Kelompok Kecil

\begin{tabular}{|c|c|c|c|}
\hline No & Aspek & Indikator & Jumlah Butir \\
\hline 1. & Media & $\begin{array}{ll}\text { a. } & \text { Kejelasan judul } \\
\text { b. Kejelasan gambar } \\
\text { c. Kejelasan penggunaan audio } \\
\text { d. Ketepatan ukuran dan jenis huruf } \\
\text { e. Kejelasan animasi } \\
\text { f. Kejelasan tampilan dan suara media } \\
\text { g. } & \text { Materi dan animasi mampu memotivasi belajar }\end{array}$ & 7 \\
\hline 2. & Materi & $\begin{array}{l}\text { a. Penggunaan contoh pada media mempermudah memahami materi } \\
\text { b. Materi pada animasi mudah dimengerti } \\
\text { c. Penyajian materi sesuai dengan yang dipelajari di sekolah }\end{array}$ & 3 \\
\hline 3. & Desain & $\begin{array}{l}\text { a. Kemenarikan animasi } \\
\text { b. Kemenarikan warna yang digunakan } \\
\text { c. Kemenarikan isi materi dengan animasi } \\
\text { d. Materi mudah dipahami } \\
\text { e. Bahasa mudah dipahami } \\
\text { f. Gambar mudah dipahami }\end{array}$ & 6 \\
\hline 4 & Manfaat & Animasi mempermudah video pembelajaran & 1 \\
\hline & & Jumlah & 17 \\
\hline
\end{tabular}

Dalam penelitian pengembangan ini digunakan dua analisis data, yaitu: analisis deskriptif kualitatif dan deskriptif kuantitatif. (1) Metode analisis deskriptif kualitatif yaitu suatu cara analisis/pengolahan data dengan jalan menyusun secara sistematis dalam bentuk kalimat/kata-kata, kategori-kategori mengenai suatu objek (benda, gejala, variabel tertentu) sehingga akhirnya diperoleh kesimpulan umum (Agung, 2018). Dalam penelitian ini, teknis analisis data yang digunakan pada tujuan penelitian yang pertama adalah rancang bangun yaitu untuk mengolah data dari hasil wawancara atau hasil diskusi dengan melihat jawaban/kalimat. Sedangkan pada tujuan penelitian yang kedua adalah validitas produk menggunakan teknik analisis deskriptif kualitatif ini digunakan untuk mengolah data hasil uji coba ahli isi bidang studi, ahli desain pembelajaran, ahli media pembelajaran, uji coba perorangan, dan uji coba kelompok kecil dengan melihat tanggapan, saran, dan kritik dari hasil wawancara, dan kuesioner. (2) Metode analisis deskriptif kuantitatif ialah suatu cara pengolahan data yang dilakukan dengan jalan menyusun secara sistematis dalam bentuk angka-agka dan atau presentase, mengenai suatu objek yang diteliti, sehingga diperoleh kesimpulan umum (Agung, 2018). Dalam penelitian ini teknis analisis data yang digunakan pada tujuan penelitian yang pertama adalah rancang bangun yaitu menggunakan kuesioner yang diberikan kepada analisis karakteristik peserta didik yang menghasilkan nilai/skor. Sedangkan pada tujuan penelitian yang kedua adalah validitas produk ini digunakan untuk mengolah data hasil uji coba ahli isi bidang studi, ahli desain pembelajaran, ahli media pembelajaran, uji coba perorangan, dan uji coba kelompok kecil menggunakan evaluasi formatif dengan mengkonversikan berupa skor/nilai. 


\section{HASIL DAN PEMBAHASAN}

Hasil

Hasil penelitian pengembangan ini dibahas dua hal pokok, yaitu rancang bangun media video animasi dan validitas media video animasi. Pengembangan media yang dilakukan pada penelitian ini menggunakan model pengembangan ADDIE yang meliputi tahapan analisis (analyze), tahap desain (design), tahap pengembangan (development), tahap implementasi (implementation), dan tahap evaluasi (evaluation). Pada rancang bangun video animasi digunakan lima tahapan model pengembangan ADDIE sebagai berikut. Tahap analisis, yaitu: (1) analisis karakteristik siswa dan permasalahan di sekolah, (2) analisis kurikulum, dan (3) analisis fasilitas atau lingkungan di sekolah. Kegiatan analisis karakteristik siswa dilakukan untuk mengetahui karakter siswa pada proses pembelajaran. Dari hasil wawancara bersama guru wali kelas III didapatkan informasi bahwa siswa tergolong aktif jika belajar menggunakan media audio visual dan dari hasil angket yang disebarkan kepada siswa melalui alamat rumah masingmasing diketahui bahwa siswa cenderung lebih suka belajar dengan video pembelajaran. Hasil analisis kurikulum disajikan pada Tabel 4. Kegiatan analisis kurikulum tentunya dilakukan untuk mengetahui kompetensi yang digunakan dalam proses pembelajaran dan kompetensi pembelajaran Tematik yang digunakan mengacu pada Kurikulum 2013.

Tahap desain, kegiatan yang dilakukan pada tahap desain ini meliputi pembuatan flowchart dan storyboard yang digunakan pedoman untuk melakukan pembuatan produk pada tahap pengembangan. Kemudian pada tahapan ini juga dilakukan pemilihan software yang digunakan untuk mengembangkan produk. Adapun software yang digunakan untuk mengembangkan produk media video animasi yaitu aplikasi Powtoon, Filmora, dan Corel Draw. Tahap pengembangan, kegiatan ini merupakan penggabungan media seperti materi pelajaran, animasi, teks, narasi, audio dan sebagainya dengan bantuan software development yang digunakan untuk mengembangkan video animasi menjadi media yang utuh. Dalam proses pengembangan tersebut sesuai dengan materi, animasi, teks, narasi, dan audio agar saling menyatukan satu sama lain. Hasil pengembangan media di sajikan pada Gambar 1.

Tabel 4. Analisis Materi Pembelajaran

\begin{tabular}{|c|c|c|}
\hline No & Kompetensi dasar & Indikator \\
\hline 3.4 & $\begin{array}{l}\text { Menggeneralisasi ide pecahan } \\
\text { sebagai bagian dari } \\
\text { keseluruhan menggunakan } \\
\text { benda-benda konkret. } \\
\text { Menyajikan pecahan sebagai } \\
\text { bagian dari keseluruhan } \\
\text { menggunakan benda-benda } \\
\text { konkret. }\end{array}$ & $\begin{array}{l}\text { 3.4.1 mengidentifikasi pecahan sebagai bagian dari benda } \\
\text { konkret dengan tepat. } \\
\text { 3.4.2 mengingat kembali pecahan sebagai bagian dari benda } \\
\text { konkret dengan tepat. } \\
\text { 4.4.1 menyajikan pecahan menggunakan benda konkret } \\
\text { dengan benar. } \\
\text { 4.4.2 menyebutkan pecahan menggunakan benda konkret } \\
\text { dengan benar. }\end{array}$ \\
\hline No & Kompetensi dasar & Indikator \\
\hline 3.4 & $\begin{array}{l}\text { Menggeneralisasi ide pecahan } \\
\text { sebagai bagian dari } \\
\text { keseluruhan menggunakan } \\
\text { benda-benda konkret. } \\
\text { Menyajikan pecahan sebagai } \\
\text { bagian dari keseluruhan } \\
\text { menggunakan benda-benda } \\
\text { konkret. }\end{array}$ & $\begin{array}{l}\text { 3.4.1 membandingkan dua pecahan berpembilang sama } \\
\text { dengan benar. } \\
\text { 3.4.2 membandingkan dua pecahan berpembilang sama } \\
\text { dengan tepat. } \\
\text { 4.4.1 menyajikan perbandingan dua pecahan berpembilang } \\
\text { sama dengan tepat. } \\
\text { 4.4.2 menyebutkan perbandingan dua pecahan } \\
\text { berpembilang sama dengan tepat. }\end{array}$ \\
\hline No & Kompetensi dasar & Indikator \\
\hline 3.5 & $\begin{array}{l}\text { Menjelaskan dan melakukan } \\
\text { penjumlahan dan pengurangan } \\
\text { pecahan berpenyebut sama. } \\
\text { Menyelesaikan masalah } \\
\text { penjumlahan dan pengurangan } \\
\text { pecahan berpenyebut sama. }\end{array}$ & $\begin{array}{l}\text { 3.5.1 menjelaskan cara penjumlahan pecahan berpenyebut } \\
\text { sama dengan baik. } \\
\text { 3.5.2 mengingat kembali cara penjumlahan pecahan } \\
\text { berpenyebut sama dengan benar. } \\
\text { 4.5.1 menyelesaikan masalah sehari-hari yang melibatkan } \\
\text { penjumlahan berpenyebut sama dengan benar. } \\
\text { 4.5.2 menyebutkan masalah sehari-hari yang melibatkan } \\
\text { penjumlahan berpenyebut sama dengan tepat. }\end{array}$ \\
\hline No & Kompetensi dasar & Indikator \\
\hline 3.5 & $\begin{array}{l}\text { Menggeneralisasi ide } \\
\text { sebagai } \quad \text { bagian }\end{array}$ & $\begin{array}{l}\text { 3.5.1 menjelaskan cara penjumlahan pecahan berpenyebut } \\
\text { sama dengan baik. }\end{array}$ \\
\hline
\end{tabular}




\begin{tabular}{ll}
\hline keseluruhan menggunakan & $\begin{array}{c}3.5 .2 \text { mengingat kembali cara penjumlahan pecahan } \\
\text { berpenyebut sama dengan benar. }\end{array}$ \\
$\begin{array}{l}\text { Menda-benda konkret. } \\
\text { bagian darikan pecahan sebagai } \\
\text { menggunakan keseluruhan } \\
\text { konkret. }\end{array}$ & $\begin{array}{l}\text { 4.5.1 } \\
\text { menyelesaikan masalah sehari-hari yang melibatkan } \\
\text { penjumlahan berpenyebut sama dengan benar. }\end{array}$ \\
\end{tabular}

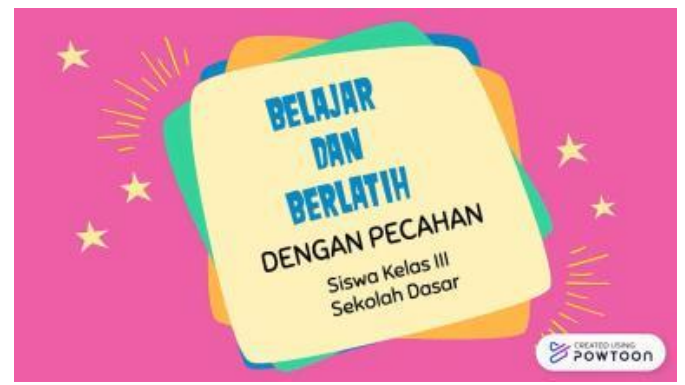

Tampilan awal

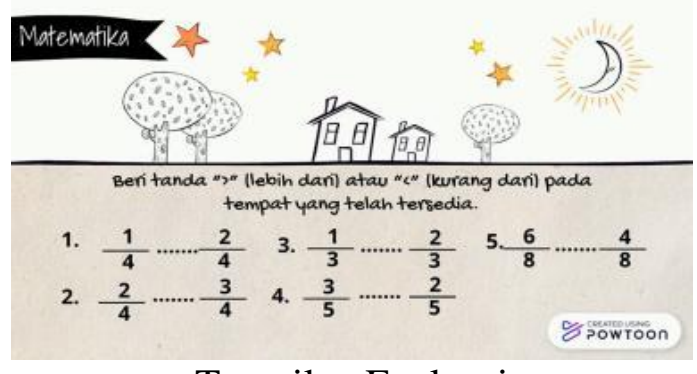

Tampilan Evaluasi

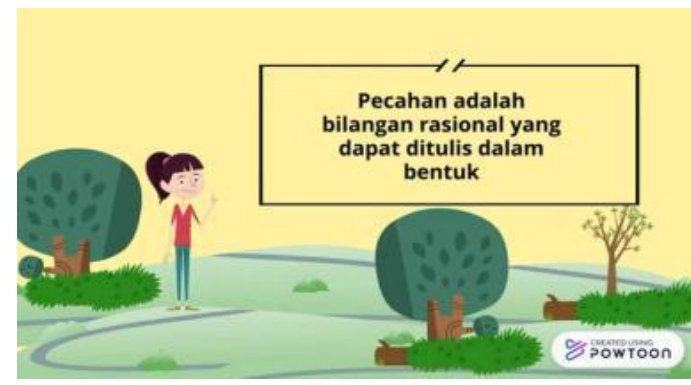

Tampilan Isi

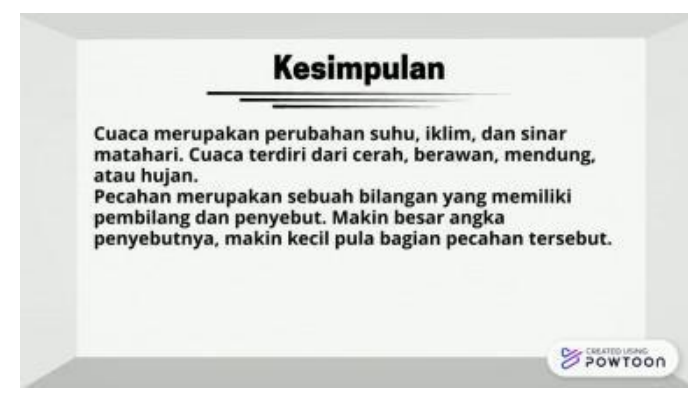

Tampilan Penutup

Gambar 1. Hasil Pengembangan Media

Tahap implementasi, kegiatan yang dilakukan (1) uji validasi media video animasi yang berdasarkan aspek dari isi pembelajaran oleh ahli isi pembelajaran, (2) uji validasi Video Animasi berdasarkan aspek desain oleh ahli desain pembelajaran, (3) uji validasi media Video Animasi berdasarkan aspek oleh ahli media pembelajaran, (4) uji coba perorangan, yang berujuan untuk mengetahui kelayakan dan kualitas dari media video animasi ini yang dikembangkan. Berikut hasil validitas yang bertujuan untuk kelayakan dari produk tersebut. Adapun hasil validitas video animasi, secara lebih detail disajikan pada Tabel 5.

Tabel 5. Hasil Uji Validitas Produk

\begin{tabular}{clcc}
\hline No & \multicolumn{1}{c}{ Subyek Uji Validitas } & Hasil Validitas & Keterangan \\
\hline 1 & Uji Ahli Desain Pembelajaran & $88 \%$ & Baik \\
2 & Uji Ahli Media Pembelajaran & $95 \%$ & Sangat Baik \\
3 & Uji Ahli Isi Pembelajaran & $94 \%$ & Sangat Baik \\
4 & Uji Coba Perorangan & $93,34 \%$ & Sangat Baik \\
5 & Uji Coba Kelompok Kecil & $92,94 \%$ & Sangat Baik \\
\hline
\end{tabular}

Berdasarkan hasil analisis data penilaian yang diberikan oleh ahli desain pembelajaran nilai yang didapatkan yaitu 88\% dengan kualifikasi baik. Berdasarkan hasil analisis data penilaian yang diberikan oleh ahli media pembelajaran nilai yang didapatkan yaitu 95\% dengan kualifikasi sangat baik. Berdasarkan hasil analisis data penilaian yang diberikan oleh ahli isi pembelajaran nilai yang didapatkan yaitu $94 \%$ dengan kualifikasi sangat baik. Berdasarkan hasil analisis data penilaian uji coba perorangan nilai yang didapatkan yaitu 93,34\% dengan kualifikasi sangat baik. Berdasarkan hasil analisis uji coba kelompok kecil mendapatkan 92,94\% dengan sangat baik. Jadi, media video pembelajaran berbasis pendekatan kontekstual layak digunakan dalam pembelajaran. 


\section{Pembahasan}

Hasil penelitian menunjukkan bahwa media video pembelajaran berbasis pendekatan kontekstual layak digunakan dalam pembelajaran. Hal ini disebabkan oleh beberapa faktor yaitu sebagai berikut. Pertama, media video animasi sesuai berdasarkan hasil analisis kebutuhan dengan model yang dikembangkan yaitu model ADDIE dengan secara sistematis dan berpijak pada teori. Proses pengembangan media video animasi berpendekatan kontekstual ini mengacu pada model pengembangan ADDIE, sehingga berimplikasi pada kelayakan produk media video animasi yang dihasilkan dalam proses pengembangan (Kurniawan et al., 2017; Siddiq et al., 2020). Pengembangan media video animasi yang mengacu pada model pengembangan ADDIE efektif dan mampu membantu proses pembelajaran siswa dan guru. Selain itu, hasil penelitian dari (Anwariningsih \& Ernawati, 2013; Ariantini et al., 2019) menyatakan bahwa media video animasi membantu pembelajaran secara keseluruhan dan memperoleh persentase sangat baik. Hasil penelitian yang menyatakan bahwa penggunaan media video animasi dapat meningkatkan hasil belajar dan motivasi belajar siswa (Ariani et al., 2021; Candra Dewi \& Negara, 2021; Hanif, M., 2020). Video animasi yang dikembangkan mmapu membantu siswa dalam proses pembelajaran dan mampu mempermudah memahami materi dengan baik. Siswa sering cenderung sangat jenuh saat mengikuti pembelajaran tanpa menggunakan media video animasi dan kurangnya motivasi siswa dalam proses pembelajaran (Sukarini \& Manuaba, 2021; Prasetya et al., 2021).

Kedua, pemanfaatan media video animasi dalam pembelajaran mampu mempermudah pemahaman serta memperkuat ingatan siswa dengan memahami materi dalam video animasi mengaitkan kegiatan yang ada dalam kehidupan siswa sehari-hari (Candra Dewi \& Negara, 2021). Video animasi pembelajaran hasil pengembangan ini didesain sedemikian rupa agar dapat menampilkan tulisan (teks), gambar-gambar berwarna, audio (suara), dan animasi dalam satu kesatuan sehingga mampu mem berikan daya tarik tersendiri kepada siswa untuk belajar lewat sajian materi audio visual (Omer, 2016; Ponza et al., 2018). Video pembelajaran mampu memberikan warna baru untuk membantu siswa dalam meningkatkan hasil belajar dan mempermudah guru untuk menyampaikan pembelajaran (Kurniawan et al., 2017; Tegeh et al., 2019; Gae, N. A., Ganing, N. N., \& Kristiantari, M. G., 2021). Media video mempunyai strategi penyampaian yang baik dengan perpaduan kontekstual pada unsur materi dalam media pembelajaran yang berimplikasi pada penyampaian materi yang efektif dan membangkitkan semangat siswa dalam proses pembelajaran. Selain itu, video pembelajaran mampu menyajikan unsur warna, bunyi, gerakan, dengan suatu proses penjelasan, dan dapat mengkoordinasikan media dengan slide, foto, dan gambar yang mampu meningkatkan motivasi siswa agar agar pembelajaran secara bervariasi dan mampu menumbuhkan rasa ingin tahu yang lebih banyak (Kurniawan et al., 2017; Wuryanti \& Kartowagiran, 2016; Jampel, A. S. I. N., \& Suwatra, I. W., 2013).

Temuan penelitian sebelumnya menyatakan bahwa video pembelajaran membantu mempermudah proses pembelajaran siswa (Octavyanti \& Wulandari, 2021; Yendrita \& Syafitri, 2019; Yusuf, M. M., Amin, M., \& Nugrahaningsih, N., 2017). Temuan penelitian yang lainnya menyatakan bahwa video pembelajaran membantu meningkatkan motivasi siswa dalam proses pembelajaran dan mampu mempermudah guru dalam proses pembelajaran (Hendrawati 2013; Karyani et al., 2013; Badra, I. G. A. O., Putu, I. D. K. T. L., \& Mahadewi, P., 2013). Temuan penelitian lainnya menyatakan bahwa pengunaan video animasi sangat berpengaruh dan sangat membantu siswa dalam pembelajaran dan keterampilan siswa. Selain itu, keterampilan siswa dapat diwujudkan jika guru mampu menerapkan pembelajaran menggunakan media yang inovatif. Hal ini merupakan salah satu kompetensi guru professional (Lestari \& Mustadi, 2020). Video pembelajaran merupakan media video yang merangsang pikiran siswa, perasaan, dan kemauan siswa untuk memiliki ide dan gagasan, pesan dan informasi secara audio visual (Wisada et al., 2019). Peran guru dalam penggunaan dan produksi video pendidikan akan dibagi di antara penyedia konten, desain, produksi, presentasi, dan pemasaran khusus (Laaser \& Toloza, 2017). Kelebihan dari media video animasi yang dikembangkan yaitu media video dengan perpaduan animasi dengan pola gerakan, warna, audio, konten materi, serta evaluasi untuk mengukur sejauh mana pengetahuan dan pemahaman kepada siswa. Implikasi penelitian ini yaitu video animasi ini mampu membangkitkan motivasi siswa dan mempermudah siswa dan guru selama proses pembelajaran. Dengan demikian, kegiatan belajar bisa terjadi dimana saja dan kapan saja.

\section{SIMPULAN}

Berdasarkan hasil analisis, uji coba kelompok kecil mendapatkan kategori sangat baik. Jadi, media video pembelajaran berbasis pendekatan kontekstual layak digunakan dalam pembelajaran. Media video animasi sesuai berdasarkan hasil analisis kebutuhan dengan model yang dikembangkan yaitu model ADDIE dengan sistematis dan berpijak pada teori. Pemanfaatan media video animasi dalam pembelajaran mampu 
mempermudah pemahaman serta memperkuat ingatan siswa dengan memahami materi dalam video animasi mengaitkan kegiatan yang ada dalam kehidupan siswa sehari-hari.

\section{DAFTAR RUJUKAN}

Angga, P. M. W., Sudarma, I. K., \& Suartama, I. K. (2020). E-Komik Pendidikan untuk Membentuk Karakter dan Meningkatkan Hasil Belajar Siswa Kelas V pada Mata Pelajaran Bahasa Indonesia. Jurnal Edutech Undiksha, 8(2), 93. https://doi.org/10.23887/jeu.v8i2.28920.

Antika, H., Priyanto, W., \& Purnamasari, I. (2019). Pengaruh Penggunaan Media Animasi Sandisko dengan Model Somatic Auditory Visualization Intellectually terhadap Hasil Belajar Tema Kebersamaan Kelas 2. Mimbar Ilmu, 24(2), 247. https://doi.org/10.23887/mi.v24i2.21288.

Anwariningsih, S. H., \& Ernawati, S. (2013). Development of Interactive Media for ICT Learning at Elementary School Based on Student Self Learning. Journal of Education and Learning (EduLearn), 7(2), 121-128. https://doi.org/10.11591/edulearn.v7i2.226.

Ariani, N. K., Widiana, I. W., \& Ujianti, P. R. (2021). Media Video Animasi untuk Meningkatkan Listening Skill Anak Usia Dini. 9, 43-52. http://dx.doi.org/10.23887/paud.v9i1.35690.

Ariantini, I. P. D., Sudatha, I. G. W., \& Tegeh, I. M. (2019). Berbasis Microlearning pada Kelas III Sekolah Dasar Mutiara Singaraja Tahun Pelajaran 2018 / 2019. EDUTECH Universitas Pendidikan Ganesha, 7(1), 23-32. http://dx.doi.org/10.23887/jeu.v7i1.19973.

Awalia, I., Pamungkas, A. S., \& Alamsyah, T. P. (2019). Pengembangan Media Pembelajaran Animasi Powtoon pada Mata Pelajaran Matematika di Kelas IV SD. Kreano, Jurnal Matematika Kreatif-Inovatif, 10(1), 49-56. https://doi.org/10.15294/kreano.v10i1.18534.

Ayuningsih, K. (2017). Pengaruh Video Animasi terhadap Hasil Belajar Kognitif pada Mata Pelajaran IPS Materi Menghargai Jasa Pahlawan di Kelas V SDN Sidokumpul Sidoarjo. JICTE (Journal of $\begin{array}{lllll}\text { Information and Computer Technology } & \text { Education), }\end{array}$ https://doi.org/10.21070/jicte.v1i1.1129.

Berbantuan, P., Pbk, K., Mata, D., Pelajaran, T., Sd, D. I., Bebetin, N., Hendrawati, M. V., Pudjawan, I. K., \& Sudatha, I. G. W. (2013). Pengembangan Video Pembelajaran Dengan Model Pelajaran Matematika Pada Siswa Kelas Iv Semester Ganjil Jurusan Teknologi Pendidikan , Fakultas Ilmu Pendidikan.

Buchdadi, A. D., Oktafianto, E., \& Mardiyati, U. (2018). Pengaruh R\&D Expenditure terhadap Firm Performance pada Perusahaan yang Terdaftar di Bei Periode 2003-2015. JRMSI - Jurnal Riset Manajemen Sains Indonesia, 9(2), 337-351. https://doi.org/10.21009/jrmsi.009.2.09.

Candra Dewi, N. M. L., \& Negara, I. G. A. O. (2021). Pengembangan Media Video Animasi IPA pada Pokok Bahasan Sistem Pernapasan Kelas V. Jurnal Edutech Undiksha, 9(1), 122-130. https://doi.org/10.23887/jeu.v9i1.32501.

Karyani, N. N. A., Jampel, N., \& Sudatha, G. W. (2013). Pengembangan Video Pembelajaran dengan Model Pembelajaran Berbantu Komputer (PBK) dalam Mata Pelajaran Bahasa Indonesia pada Siswa Kelas VIII Semester Genap Tahun Pelajaran 2012/2013 di SMPN 1 Sukasada. Jurnal Teknologi Pendidikan, 1-10. http://dx.doi.org/10.23887/jeu.v9i2.38646.

Kasih, F. R. (2017). Pengembangan Film Animasi dalam Pembelajaran Fisika pada Materi Kesetimbangan Benda Tegar di SMA. Tadris: Jurnal Keguruan Dan Ilmu Tarbiyah, 2(1), 41. https://doi.org/10.24042/tadris.v2i1.1737.

Kurniawan, Agung, \& Tegeh. (2017). Pengembangan Video Pembelajaran Teknik Dasar Sepak Bola dengan Konsep Quantum Learning. Jurnal Edutech Undiksha, 5(2), 179-188.

Laaser, W., \& Toloza, E. A. (2017). The Changing Role of the Educational Video in Higher Distance Education. International Review of Research in Open and Distance Learning, 18(2), 264-276. https://doi.org/10.19173/irrodl.v18i2.3067.

Lestari, B., \& Mustadi, A. (2020). Animated video media vs comic on storytelling skills for fifth-grader: Which one is more effective? Journal for the Education of Gifted Young Scientists, 8(1), 167-182. https://doi.org/10.17478/jegys.664119.

Octavyanti, N. P. L., \& Wulandari, I. G. A. A. (2021). Pengembangan Video Pembelajaran Berbasis Pendekatan Kontekstual pada Mata Pelajaran Matematika Kelas IV SD. Jurnal Edutech Undiksha, 9(1), 66-74. https://doi.org/10.23887/jeu.v9i1.32223.

Omer, T. (2016). Nursing Students's Perceptions of Satisfaction and Self-Confidence with Clinical Simulation Experience. Journal of Education and Practice, 7(5), 131-138. www.iiste.org.

Ponza, P. J. R., Jampel, I. N., \& Sudarma, I. K. (2018). Pengembangan Media Video Animasi pada Pembelajaran Siswa Kelas IV di Sekolah Dasar. Jurnal Edutech Undiksha, 6(1), 9-19. http://dx.doi.org/10.23887/jeu.v6i1.20257.

Pratiwi, L. (2018). Media Video: Solusi Pembelajaran IPS bagi Siswa Sekolah Dasar. 337-349. 
Risdant, B., Teks, P., Pada, N., Kelas, S., \& Ma, X. I. (n.d.). Media Development Based on Animation for Learning Text Negotiation in Students Grade XI MA.

pSiddiq, Y. I., Sudarma, I. K., \& Simamora, A. H. (2020). Pengembangan Animasi Dua Dimensi pada Pembelajaran Tematik untuk Siswa Kelas III Sekolah Dasar. Jurnal Edutech Undiksha, 8(2), 49. https://doi.org/10.23887/jeu.v8i2.28928.

Sukarini, K., \& Manuaba, I. B. S. (2021). Pengembangan Video Animasi Pembelajaran Daring pada Mata Pelajaran IPA Kelas VI Sekolah Dasar. Jurnal Edutech Undiksha, 9(1), 48-56. https://doi.org/10.23887/jeu.v9i1.32347.

Tegeh, I. M., Simamora, A. H., \& Dwipayana, K. (2019). Pengembangan Media Video Pembelajaran dengan Model Pengembangan 4D pada Mata Pelajaran Agama Hindu. Mimbar Ilmu, 24(2), 158. https://doi.org/10.23887/mi.v24i2.21262.

Wisada, P. D., Sudarma, I. K., \& Yuda S, A. I. W. I. (2019). Pengembangan Media Video Pembelajaran Berorientasi Pendidikan Karakter. Journal of Education Technology, 3(3), 140. https://doi.org/10.23887/jet.v3i3.21735.

Wuryanti, U., \& Kartowagiran, B. (2016). Pengembangan Media Video Animasi untuk Meningkatkan Motivasi Belajar dan Karakter Kerja Keras Siswa Sekolah Dasar. Jurnal Pendidikan Karakter, 6(2), 232-245. https://doi.org/10.21831/jpk.v6i2.12055.

Yendrita, Y., \& Syafitri, Y. (2019). Pengaruh Penggunaan Media Video Pembelajaran terhadap Hasil Belajar Biologi. BIOEDUSAINS: Jurnal Pendidikan Biologi Dan Sains, 2(1), 26-32. https://doi.org/10.31539/bioedusains.v2i1.620. 